\title{
After the good life: squatting and the politics of the commons in The good terrorist
}

\begin{abstract}
This essay focuses on the representation of squatting as a form of 'commoning' in Doris Lessing's The good terrorist (1985). It argues that the text's centring of the act of squatting suggests a starting point for a politics rooted in everyday actions of home/making and community building, a model that relies on the power of the common - defined, following Raymond Williams, as what is ordinary and what is shared. Even as it posits the radical potential of squatting, the narrative's imagining of gender politics, together with its 'temporality of despair', undermines the legitimacy of commoning as a sustainable form of social organisation. The article seeks to understand the conditions under which everyday life in Lessing's London is brought about and sustained through a marking off of the possible and finds its historical analogue in the Thatcher-era slogan 'There is no alternative'. The good terrorist is a narrative of 'enclosure' in which tragedies occur as the logical outcome of trying to find alternatives to the exigencies of the world as it is. It asks, if Lessing's novel is one of 'enclosure', what might a novel look like that performs its opposite? Can we conceive a literature of the commons?
\end{abstract}

Keywords: women's writing, commons, housing, squatting, demunicipalisation

This essay reads Doris Lessing's The good terrorist against the backdrop of the rapidly disintegrating 'social consensus' under Margaret Thatcher. I focus on the novel's representation of housing policy in order to explore the ways Thatcher's Conservative government, through a sustained attack on the authority of municipal councils, advanced a free market political philosophy that today is pervasive and has come to seem inevitable. The good terrorist foregrounds these contemporary political issues in its centring of the act of squatting, which had reached an all-time high in the 1980s, even as it was on the decline in its 
organised, overtly political form. In highlighting the act of squatting, the novel offers a starting point for a politics rooted in everyday actions of home/making and community building. It presents a model that relies on the power of the common - which I define, following Raymond Williams (1983: 71), as what is ordinary and what is shared - and that runs on a temporality of 'commoning', a threshold temporality whose porousness 'create[s] or symbolically represent[s] passages towards a possible future, already existing in the past' (Stavrides 2016: 71). At the same time, although it creates a space of possibility within the text, the radical potential of 'commoning' is constrained by the narrative's temporality of despair and crisis. The narrative form of The good terrorist ultimately undermines the legitimacy of commoning as a form of sustainable social organisation.

The novel follows Alice Mellings and Jasper, her abusive partner with whom she has a nonsexual relationship, from the time they move into a squat at 43 Old Mill Road, London, and charts the squat's transformation from 'commune' to hideout to weapons cache. Gayle Greene (1992: 204) argues that the text registers 'the dimming of the great social dream' from the 'golden age of the sixties' through the Thatcher years 'of rising unemployment and riotless gloom', but readings that place the novel in historical perspective do not get much more specific than that. Critics have focussed much of their attention on the activities and muddy ideological attachments of the activist commune to which Alice belongs, the Communist Centre Union or CCU, or else on Alice herself, standing in for what Gillian Bright (2015: 202) has called a 'terrorist housewife', a figure who is at once nurturing and destructive. These readings concentrate on the CCU's act of terrorism - their bombing of a street outside a posh hotel in Knightsbridge in the novel's climactic scene - which is variously interpreted as a symptom of despair about language, action, and the future. ${ }^{1}$ Despair, in short, abounds in readings of The good terrorist. The novel, as Greene (1993:

\footnotetext{
${ }^{1}$ Margaret Scanlan's 1990 essay addresses The good terrorist's despair about language and action together.
} 
313) points out, 'offers none of the usual consolations of narrative: that what we do in the past accounts for the present, that what we do in the present affects the future ... that the next generation will do better than the last'. I do not want to deny this despair, exactly, but what I do want to do in this essay is to complicate this despair by historicising it more clearly, and to do this I will begin by looking at the house that is central to the novel, and which is often overlooked in readings that centre the bombing, the squat at 43 Old Mill Road, a fictitious address.

\section{Home/making}

In Lessing's London, uninhabited houses are scheduled for demolition to make space for 'enormous buildings [not wanted] by anyone but the people who made a profit out of them' (Lessing 1985: 18-9). Meanwhile, the houses are actually rendered uninhabitable by workmen hired by the Council to prevent squatters 'regularising' the arrangement. The novel opens as Alice and Jasper enter the squat at 43 Old Mill Road and take stock of the damage the workmen have done: two toilets whose bowls are filled with cement, a cooker pulled away from the wall in the kitchen, wiring torn out. This kind of profit-driven creative destruction is a feature of urban redevelopment and regeneration projects and was facilitated by Thatcher-era initiatives like Enterprise Zones, which were exempt from local government regulations and designed to encourage entrepreneurialism. In The autonomous city, Alexander Vasudevan (2017: 43) describes squatting as the 'political other' to this creative destruction: it is an expression of 'collective world-making: a place to express anger and solidarity, to explore new identities and different intimacies, to experience and share new feelings, and to defy authority and live autonomously'. In this way, squatters literally build alternative worlds: once Alice has ascertained the extent of the damage, she proceeds, methodically, to execute, delegate, or share the tasks that will make the house liveable. Her first act is to get the toilets and sinks unblocked. For this, she enlists the help of Philip, a 
skilful contractor whose timidity and physical frailty lead to his repeatedly being taken advantage of by employers. Because she is aware she cannot pay him adequately, Alice undertakes to convince the other members of the squat to allow Philip to move in in exchange for his labour. This is one of the points at which Alice's squatting moves beyond a transient kind of anarchist politics and becomes 'commoning'.

'Commoning', or the practice of 'doing in common', creates and reinvents shared spaces and ways of living and new forms of social cooperation (de Angelis 2016: xiii). Crucially, if it is to look beyond the dynamics of Capital, commoning must gesture towards the 'development of a variety of community-based structures' to ensure its reproduction (Federici 2012: 12). For Stavros Stavrides (2016), a practice of commoning that looks beyond the dynamics of capitalism must be expansive (always forming potential links between strangers and creating the possibility of exchange between them) and must be negotiated through an ongoing process of collaboration. 'Ongoingness' is important here: a commoning practice that can prefigure an 'emancipated society' is always in progress (Stavrides 2016: 39). A common space, through the everyday ordinary actions of the people who populate it, is 'a relation between a social group and its effort to define a world that is shared between its members' (Stavrides 2016: 55). Its rules and its vision are suggested by the way the participants work together, its reproduction a form of repetition with variation so that it can accommodate new members without interpellating them into an existing organisation of roles. Thus, the ideal is that the common space is a democratic space whose citizenship is determined by participation in and engagement with the collective.

Since 'the house is the oikos on which the economy is built', it is, for Silvia Federici, the home which must be claimed 'as a centre of collective life' (2012: 147). Squatting is, then, a key component of commoning - of creating and extending common spaces. And it is this practice of expansion that Alice is attempting in her practice of squatting. She 
undertakes, methodically, to restore the plumbing, the electricity, to clear the rubbish from the garden, to repair the kitchen, to add touches of hominess to the house, and does so by enlisting the help of various members of the squat, all the while refusing any particular leadership role. She works to have Philip admitted to the squat in exchange for his work on the house, and then Mary, who works at the local council's housing office, and then Mary's husband Reg. She convinces the other activist squatters to allow Jim, the squat's original occupant, to stay. Her logic at the start of the novel is one of openness and of expansion, and her happiest moment in the text occurs when the house hosts the CCU congress, and activists of different stripes arrive to cook, organise, debate and plan together. Some of the women attendees organise women's-only spaces; others organise a crèche. In short, the way Alice occupies and rebuilds the squat is a political act because it reimagines and reclaims the home as a common space. Further, her efforts to clear the rubbish from the yard and to get the neighbours on side by presenting a face of respectability are her way of modelling a viable example of collective living and social transformation. Her squatting then comes to constitute a practice of commoning that is projective, which is to say it suggests 'possible forms of life in common' (Stavrides 2016: 2). And it is precisely this imaginative reach, made concrete in the act of squatting, that is crucial, because, as Stavrides points out, commoning's means are its ends. Its practice is also a form of description (rather than prescription) in that it produces a series of possible narratives and potential ways of being in the world. Similarly, the ideal of the common, according to Federici, is that it offers 'a logical and historical alternative to both State and Private Property, the State and the Market, enabling us to reject the fiction that they are mutually exclusive and exhaustive of our political possibilities' (2012: 139). In this way, it serves a narrative function: just as commoning is projective, so it is also expressive of the values of the community and exemplary in the way it partially establishes, even as it imagines, 'social relations that exceed the limits imposed by dominant modes of sociality' 
(Stavrides 2016: 2). Thus, in representing the act of commoning, The good terrorist posits the radical potential of narrative itself: it partially realises what it describes. This is another way in which squatting is the political other to 'creative destruction': not only does it challenge housing precarity and the practice of property speculation, but it is 'also a place where one [can] (quite literally) build an alternative world' (Vasudevan 2017: 10-12). In the act of restoring and of living communally in a house, then, the practice of squatting generates and enables the flourishing of new forms of social organisation just as squatters reimagine and rebuild the physical spaces they inhabit.

Crucial to the task of building 'an alternative society and a strong self-reproducing movement,' according to Silvia Federici (2012: 147), is redefining, 'in more cooperative ways our reproduction [and putting to] an end the separation between the personal and the political, political activism and the reproduction of everyday life'. But as Lessing's narrative progresses, what becomes clear is that the promise of the common life which the squat offers is contingent and restricted. Jim, for instance, is ostracised by the CCU members of the squat for his lack of political allegiance. And it is in the CCU's attitude to Jim that the fault lines are clearly drawn between squatting's capacity to expand the common network, and squatting as it is actually lived and represented in the 1980s of The good terrorist. In commons discourse, the practice of commoning itself enacts politics through its manifestation or representation. ${ }^{2}$ Jim's occupation of the house is, on this reading, on its own a political act. But for the CCU, Jim's squatting is not political because it is borne of necessity: for the CCU activists who read Marx and Althusser, who hang a portrait of Lenin on the lounge wall, it is doctrine that should determine the course of action and that defines the horizon of politics. Rather than espousing a transformative politics shaped by the way they live together in the

\footnotetext{
${ }^{2}$ Here I draw on Stavrides's definition of politics as 'an open process through which dominant forms of living together are questioned and potentially transformed' (2016: 55).
} 
squat, the activists promote an approach to politics that is ideological and thus predetermined. Their attitude to Jim, moreover, reproduces within the squat the dominant taxonomy of roles in the outside world. Jim is black, working class, uneducated and sidelined by the activists who claim to be working for the greater good; they would claim to be working for people like Jim without recognising the ways their actions reproduce inequality. Instead of extending common space, the members of the CCU adhere to the logic of enclosure and exclusion that is characteristic of the capitalist class's crisis strategy of ‘primitive accumulation' (Federici \& Caffentzis 2014: 94). This reproduction of inequality is one of the ways in which Lessing's squatters make recourse to the system they nominally oppose.

I have already suggested that the activity of homemaking in the squat presents, in the novel, a starting point for a politics rooted in the home and in the everyday and that models an alternative form of social organisation. Upon closer analysis, though the text raises squatting's potential for collective world making through Alice, this possibility is constrained in two crucial ways: first, by the novel's imagining of gender politics; and second, by the narrative's temporality of despair that overwhelms the radical potential of the threshold temporality of commoning. Federici \& Caffentzis (2014: 101) argue that the commons depends on the reproduction of 'our' lives, a reproduction which depends also upon the reproduction of 'their' lives: 'we need, to overcome,' Federici writes elsewhere, 'the state of constant denial and irresponsibility concerning the consequences of our actions resulting from the destructive ways in which the social division of labour is organized in capitalism; short of that, the production of our life inevitably becomes a production of death for others' (Federici 2012: 145). As the initial enthusiasm for Alice's homemaking efforts wears off, the rigidity of the division of labour within the house becomes clear. Another woman in the squat, Pat, tells Alice that, 'I left one squat because I did all the work', and Alice responds, 
'It's always like that. There's always one or two who do the work' (Lessing 1985: 53). The work these women undertake is valuable and political: in reclaiming the home as the site of collective life, Alice and, to a lesser extent, Pat, create the basis for a movement that can reproduce itself, which Alice makes clear through her recitation of a litany of successful squatting stories:

A group of seven of us went to the Council over a scheduled house. We paid gas and electricity and water, and we stayed for thirteen months.... And in Halifax, I was in a negotiated squat for six months. And when I was in digs in Manchester, that was when I was at the university, there was a house full of students, nearly twenty of us. It started off as a squat, the Council came to terms, and it ended up as a student house. (Lessing 1985: 12)

The effect of this list is precisely to give the sense of the venture's reproducibility. It also suggests the existence of a formula for success, hinting at what Federici (2012: 12) calls 'the development of a variety of community-based structures'. Although this work is valuable, it is clear that it is not valued: Alice reflects that it was '[f]unny, she was described as unemployed, she had never had a job, and [yet] she was always busy' (Lessing 1985: 103). The labour she is expending is not seen as 'work', either by the State or by her fellow 'comrades', who see it as 'an explosion of order into their lives' (Lessing 1985: 42). ${ }^{3}$

From the very beginning, the legitimacy of Alice's activism is undermined even as it is being proposed by the way the narration maintains an ironic distance while at the same time being focalised through her. Her inability to understand the dissonance, for instance,

\footnotetext{
${ }^{3}$ Federici, in her landmark essay 'Wages against housework', originally published in 1975, makes the case that Capital has transformed housework into a natural feminine attribute so that it can avoid recognising it as a social contract and better exploit women. She argues that the struggle for wages 'against' housework is not a 'struggle to enter capitalist relations, because we have never been out of them' (Federici 2012: 18). Rather, it is a struggle that seeks to 'break capital's plan for women' by attacking 'Capital and forc[ing] it to restructure social relations in terms more favourable to us' (ibid.). She writes, '[t]o say that we want money for housework is the first step towards refusing to do it, because the demand for a wage makes our work visible, which is the most indispensable condition to begin to struggle against it' (ibid.).
} 
between her stated political commitments and her financial reliance upon her middle-class parents is dramatised in repeated scenes of temper tantrums that Alice cannot remember: she conveniently goes into fugue states at crucial moments. Her efforts to renovate the house are, moreover, portrayed as being engaged in a kind of respectability politics. Jasper accuses her of neglecting 'the Cause', always spelled with a capital-C and never fully articulated 'While you play house and gardens, pouring away money on rubbish, the Cause has to suffer, do without', he says (Lessing 1985: 160). This tension between radical politics and middleclass longing is reflected in a scene early on in the novel:

In the soft spring afternoon everything was in movement, the pastel clouds, new young leaves, the shimmering surfaces of the lawns; and when she reached her street it was full of children, cats, and gardeners. This scene of suburban affluence and calm provoked in her a rush of violent derision, like a secret threat to everything she saw. At the same time, parallel to this emotion and in no way affecting it, ran another current, of want, of longing. (Lessing 1985: 26)

Alice's desire to make the squat liveable is recalibrated in the novel as evidence of a kind of middle-class consumerism, the radical, world-making potential of her actions neutralised by a narrative imagination that cannot see beyond the horizon of Capital and so reduces all motivations to material gain and individual self-seeking. Within the world of the narrative, a form of collective living shaped by anything other than greed or will-to-power is impossible: the squat community breaks up after their bombing outside of the Knightsbridge hotel in part because the possibility of an act of 'revolutionary' violence has been the only thing keeping them together. 'But we said we were going' Jasper tells Alice, 'the moment it was done' (Lessing 1985: 363). Unlike a squatting movement (as envisioned by Alice) whose everyday acts of collective world-making make space to care and to create, a space that becomes the site of a politics which is 'an open process through which the dominant forms of living 
together are questioned and potentially transformed', the actions of Lessing's squatters are determined by a pre-existing ideology and code of behaviour that value militancy over care (Stavrides 2016: 55). In this way, Lessing shows the middle-class characters reinscribing the dominant social taxonomies the act of squatting might otherwise upset. Thus, instead of moving care to the centre of political discourse, a strategy suggested by the political theorist Joan Tronto, Alice's homemaking is necessarily limited to a kind of 'self-care divested of any orientation toward the common' (Brown 2006: 695). This, according to Wendy Brown (2006: 704), is what happens within a neoliberal political rationality: the devolution of 'both political problems and solutions from public to private' and a resulting 'dissipation of political or public life' so that 'the project of navigating the social becomes entirely one of discerning, affording and procuring a personal solution to every socially produced problem'. Alice's homemaking is figured as feeding into the middle-class logic of "penny-pinching ... saving and accumulating' and way of 'looking at people who were not themselves in that cautious, keep-off way' she claims to abhor (Lessing 1985: 152-153). Alice's imagination is constrained by her socio-economic background to which she remains wedded. The way her hypocrisy is described by the other characters in the novel, moreover, has distinctly gendered overtones.

Within the text, commoning is denigrated in terms of its association with femininity. The narrative double vision, the disjuncture between what Alice thinks of herself and what she does, turns her into an object of ridicule and even of disgust. The way Alice's fugue states blur the boundary between reality and her imagination is reflected in repeated physical descriptions in which she is described as having a 'formless' look to her, at risk of transgressing her own bodily bounds. When we first meet Alice, she is 'stocky' with a 'pudgy, formless look to her' (Lessing 1985: 12). Later, her face looks 'plump childlike [and] formless' (Lessing 1985: 54). Jasper 'hates' the look she has 'when she seemed, all of her, to 
be swollen and glistening, as if not merely her face but her whole body filled with tears which oozed from every pore' (Lessing 1985: 11). This description hints at what is supposed to be so pernicious about Alice: her inappropriate affect and the way she allows feeling to override logic. The division between feeling and logic the narrative sets up has a long and gendered history, while Alice's 'formlessness' suggests an anxiety about the uncontainable female body, an anxiety evident also in the narrator's multiple references to her as being 'childlike' a word that rhetorically undercuts any potentially transgressive sexuality. Just as Alice's feminine affect make her an object of derision in the narrative, so her squatting is translated into (and undermined by its association with) homemaking. This is a point underscored by Alice's mother, Dorothy, who calls her 'an all-purpose female drudge': 'it turned out you spend your life exactly as I did', she tells Alice: 'Cooking and nannying for other people' (Lessing 1985: 329). Dorothy thinks Alice is merely a throwback to the entrapped femininity she herself experienced, but her comment also underlines the extent to which the radical potential of everyday commoning practices, negotiations and encounters (including 'homemaking') to shape common life are neutralised by the squat's men who insist that ideology dictate action. When Jasper berates Alice for privileging the work of reclaiming the house as common space at the expense of 'the Cause', he is fetishizing militancy and 'heroic' actions 'while overlooking the modest material and emotional practices that were often central to the endurance and survival of squatted spaces' - modest material and emotional work more often than not undertaken by women (Vasudevan 2016: 117). His attitude in fact serves to reinforce traditional power structures, white and male-dominated social forms, and begins to shape how Alice thinks of herself: 'Here I am,' she comes to think, 'fussing about a 
house, while they are doing something serious' (Lessing 1985: 88). Women on the left, in Lessing's novel, are thus 'trapped in the patriarchy they despise' (Scanlan 1990: 87). ${ }^{4}$

Lessing's narrative takes pains to highlight the intersecting structures of oppression within the squat: it is clear that Alice's labour is being exploited by the other members of the CCU, while the only character of colour in the novel, Jim, who first colonised the squat, is bullied and threatened with eviction by the activists. The reproduction of inequality within the activist community, here the subordination of experiences of women and people of colour, functions metonymically - which is to say that it reflects the organisation of the world outside the squat. Resistance to the political order is here already shot through and defined by the same set of power relations of the system it ostensibly opposes. This is in keeping with the shift in squatting culture in the 1980s. In a period of industrial decline and increased inflation, which saw the deregulation of private rented housing and a sharp uptick in property speculation, rents doubled in real terms between 1979 and 1985 per year on average, exacerbating a housing crisis that the Thatcher government was denying existed (Crook 1988: 159). As a result, squatting reached an all-time high in British cities, but unlike the organised squatting of the 1960s and 70s, dominated by middle class anarchists, the new squatters were atomised, primarily working-class individuals or families. The activist squatters of the previous decades had, by and large, left the movement after their housing needs were met, and the decrease in organised squatting meant that squatting could no longer serve as an effective means of challenging the housing crisis. These historical circumstances are useful in helping us to understand the reasons for Lessing's portrayal of revolutionary politics as hypocritical and morally vacuous. For Lessing, a lifelong radical who at one time ran a home for troubled adolescents and young adults, history has shown that middle-class activists

\footnotetext{
${ }^{4}$ Pedram Lalbaksh \& Wan Roselezam Wan Yahya (2012) have previously described the ways in which Alice's position within the squat is at once exploited and undermined by a male-dominated social order, although they read the narrative as one of liberation, which I do not.
} 
reinscribe their own values at the same time as they attempt to thwart them, but also that this failure is a result of a specific set of historical circumstances. And so within the world of the text, there is no outside of the system. I agree with Margaret Scanlan's claim that the activists evince a 'complicity with power', but I would argue that, contrary to her claim that The good terrorist 'offers no other articulated alternative to the demented bomb-throwing politics of the $\mathrm{CCU}$ and the terrifying efficiencies of the intelligence services', it is the narrative's articulation and subsequent undercutting or suppression of these alternatives that shapes its political message that There is No Alternative (Scanlan 1990: 90).

\section{Temporalities of despair}

Towards the end of The good terrorist, Alice - having lived through the series of tragedies that make up the narrative - reflects that, 'marginal people, people clinging on but only just ... make one slip ... part of some downward drive in a life, and that was that' (Lessing 1985: 277). 'The relentlessness of it,' she thinks, 'the bloody shitty awfulness of it' (Lessing 1985: 278). I would like here to pick up on the aspect of 'inevitability' implicit in Alice's remark, the ways in which the 'shitty awfulness' of everyday life in Lessing's London is brought about and sustained through a marking off of the possible.

Alice is incredulous that 'anybody, particularly a member of the working class, could obey an order to destroy a house': 'particularly' because she sees it as a demonstration of a lack of solidarity with the homeless (Lessing 1985: 7). The possibility of meaningful solidarity is a question mark in the text, in part because of the ways in which precarity and contingency are represented such that they seem like the horizon of possibility for the characters: they are used to temporary addresses, unstable work, fleeting relationships. At the very moment when the community of activists in the squat seems its most secure and functional, when the narrator begins calling it a 'commune' rather than a 'squat' Alice thinks, 'Oh yes, all this love and harmony was precarious enough ... just one little thing, puff! And it 
would be gone' (Lessing 1985: 232). This moment is mirrored by a vision of impermanence Alice shares with another member of the squat, Philip. Alice and Philip, while examining the damage to the house are 'possessed, at the same moment by a vision of ... houses, buildings, streets, whole areas of streets, blown away, going, gone, an illusion. They sighed together, and on an impulse, embraced gently, comforting each other' (Lessing 1985: 124). This image, of houses, of entire streets, being blown away suggests, too, the breaking up of longstanding communities in the interest of profit: in place of 43 Old Mill Road, contractors intend to build a block of privately-owned luxury flats. Thus, the difficulty, or even impossibility, of meaningful community in the novel is bound up with the constantly shifting physical landscape of London, driven by the pursuit of profit with little regard for the consequences.

As previously discussed, the local council is throughout the text engaged in this kind of creative destruction, but is at the same time apparently invested in 'the best interests of everybody' and amenable to negotiating 'squats', at least for people like Alice who know the ropes and have the time and energy to navigate the various bureaucracies (Lessing 1985: 21). It is a tension that the narrative sets up from the very beginning through Alice's ambivalent orientation towards the council: she maligns its 'corruption' but depends upon the affective engagement not just of council employees but of the bureaucracy itself to provide assistance, as if there is a caring mechanism built into its structure. Alice successfully convinces a series of officials to stay the demolition of the building, then to get the squat regularised, and finally to get the utilities switched on. She thinks she has been successful because she has engaged the sympathies of these people, when in fact what she interprets as affect is merely an absence: as David Graeber (2012: 118) has pointed out, the problem with bureaucracies is that there is no final authority to turn to when things go wrong. Equally, the vacuum of responsibility at the heart of the bureaucracies with which Alice contends creates apathetic 
representatives who do not believe in the policies they are tasked with implementing but recognise that there is no one to appeal to. They accede to Alice's requests not because they care about her needs. In fact, they cannot afford to care because the structure of disavowal inherent in the system forestalls meaningful action. The employees do not advocate on Alice's behalf because they know there is no one, finally, to advocate to. And so they make concessions, the only kind they can make, which are minor and provisional, and usually come about as a result of Alice paying them off with money she has stolen from her parents. The utilities are switched on temporarily; the squat is initially given a two-day 'stay', but these concessions - these potentially radical acts of kindness, always offered in a spirit of resignation - are not just quickly absorbed back into the system; they are, to borrow Mark Fisher's term, 'precorporated' (2009: 9). This ethos partly accounts for the difficulty of forging or maintaining solidarity in the novel. In The good terrorist, the potentially subversive effects of affective engagement are neutralised by a system that anticipates and can therefore accommodate them.

The novel's focus on the council as the locus of this structure of disavowal points to a specific historical moment. When Alice sets out to advocate on behalf of the house, on behalf of the neighbourhood, to try make the council employees see that "what she was suggesting was ... in the best interests of everybody, the ratepayers, the public', she is appealing, naively, to a sense of public-spiritedness that has long since been superseded (Lessing 1985: 21). What is more, her reasoning depends upon a belief that the council has the means to effect these changes, or to behave rationally and 'in the best interests of everybody'. But, as Tom Crewe (2016: 8) argues, 'the basis of the inclusive welfare state [had long been] whittled away, along with its capacity to act as a rallying principle for the majority of the British public'. People, in Lessing's London, can no longer expect the services they pay for to be run in their interests. I want to argue that this contrapuntal depiction of the local authority 
- as at once benevolent and malign - speaks to the bind experienced by municipal government from the 1980s: the compromise of their democratic mandates as a result of the exigencies created by the Conservative government's withdrawal of central government funding and the introduction of Right to Buy legislation and of Enterprise Zones. The text suggests that these policies have undermined public trust in local councils, a process of disempowerment that paved the way for the hollowing out of the welfare state and its institutions.

A young woman who turns up at 43 Old Mill Road with a squalling infant and demands to be let in tells Alice that she's 'in one of those hotels, do you know about them? Well, why don't you, everyone ought to. The Council shoved us there, my husband and me and Bobby. One room. We've been there seven months... We are not allowed to cook. Can you imagine, with a baby?' (Lessing 1985: 118-9). She goes on to describe a litany of injustices and degradations, scenes of concentrated misery, and concludes: 'You ring up the Council and complain, and they say they are looking into it' (Lessing 1985: 119). It is not merely the bureaucratic set-up of the local council that muddies the issue of accountability here: in practical terms, the council's means to effect change had severely atrophied. Between 1979 and 1990 the Conservatives not only made cuts to council funding but also placed caps on the rates of spending and taxation, which encouraged business-friendly initiatives and the construction of high-value properties as the only way of increasing income: hence the council's plan for 43 Old Mill Road. In 1982, moreover, the Social Security and Housing Benefits Act combined, as Colin Hay (1992: 57) writes, 'the existing systems of rent and rate rebates with allowances, and of supplementary benefit assistance with rents [and then] transferred the administration of this welfare provision from central to local government'. This put local authorities in the position of having to implement and explain the cuts they 
were still fighting, while central government succeeded in distancing itself from the unpopular consequences of its policy objectives.

The structural crises that originated 'as a direct result of the implementation of policy objectives by central government [were] systematically displaced to become articulated as "legitimation crises" at lower levels of abstraction,' which is to say, the local authorities (Hay 1992: 58). Hay argues that these strategies were mobilised deliberately by the Thatcher government in an effort to implement what has now been the governing political philosophy of the last 35 years and that forged, according to Stuart Hall, 'new discursive articulations between the liberal discourses of the 'free market' ... and organic conservative themes of tradition, family and nation, respectability, patriarchalism and order' (Hall 1988: 2). But normalization is a process: as Stavrides (2016: 15) writes, 'It is not simply imposed, it has to infiltrate every capillary of society in order to be effective'. The successful implementation of Thatcherism thus depended in part on securing the consent of the governed, and the State accomplished this by reconstructing the material conditions of everyday life, people's experience of the day to day. Stavrides (2016: 14-15) describes the normalization project in terms of urban ordering: it uses space and relations within that space to 'encourage social relations and forms of behaviour which will be repeatable, predictable and compatible with the taxonomy of the necessary social roles'. In this way, Thatcherism infiltrated the 'capillaries' of society in a way that remoulded 'material interests within large sections of civil society from the interests of the public to the private sector' (Hay 1992: 45). Over the course of the Thatcher years, central government divested councils of much of their power and independence, and, as we have seen, of any kind of public faith in them, which left, according to Crewe (2016: 10), 'the gap between the public and their government to be bridged by private companies, if at all'. Hay (1990: 45) argues that 'this has institutionalised the impact of policy objectives and made a reversal of a potential Thatcherite settlement more 
difficult.... Thatcherism in other words has redefined not only the boundaries of political discourse but also the very nature of the "political" itself'. And this is how it comes to seem true - how it comes to seem like common sense - that There Is No Alternative.

As I have suggested, The good terrorist underscores this sense of limited horizon through the prevailing narrative temporality of despair which shares features with what anthropologists Daniel Knight \& Charles Stewart (2016) have conceptualised as a temporality of crisis in times of austerity. During moments of austerity-induced crisis, people tend to draw 'on past events to contemplate uncertain future as one strategy for resolving the aporia of crisis' (Knight \& Stewart 2016: 4). What this means is that people begin to disregard temporal distance, collapsing events of long ago into the present in order to find meaning. This temporality of despair is dramatized in Alice's fugue states and thrown into relief in the novel's final scene, in which Alice sits at the kitchen table of 43 Old Mill Road, its occupants now dispersed:
Alice did know that she forgot things, but not how badly, or how often. When her mind started to dazzle and puzzle, frantically trying to lay hold of something stable, then she always at once allowed herself - as she did now - to slide back into her childhood where she dwelt pleasurably on some scene or other that she had smoothed and polished and painted over and over again with fresh colour until it was like walking into a story. (Lessing 1985: 368)

Alice, like Knight and Stewart's interlocutors, here condenses multiple moments of the past and relives them in the present in an attempt to overcome the aporia symbolised by her fugue states. Equally, the temporality of squatting unfurls in the novel not as a threshold temporality, full of possibility, but as a series of perpetual crises in which the experience of the past determines the horizon of the future. Each leave-taking prefigures the next; each eviction sits in an experience of previous evictions. Although Alice's experience, as I have 
shown above, proves that this is not inevitable, the narrative's temporality of despair constrains the possibility of meaningful community. The sense of despair in the novel - what Greene (1992: 313) has called its 'savage nihilism' - thus suggests an acceding to what Fisher (2009: 2-9) called 'capitalist realism', where 'desires, aspirations and hopes' are 'preemptive[ly] formatted and shaped ... by capitalist culture' and where even the potential for radical action is neutralised. In the novel, the CCU in fact merely shores up the system it hopes to overthrow but which in fact it sustains.

Federici (2012: 145) argues that 'No common is possible unless we refuse to base our life, our reproduction, on the suffering of others, unless we refuse to see ourselves as separate from them. Indeed, if "commoning" has any meaning, it must be the production of ourselves as a common subject'. Within Lessing's text, it is doctrine or theory that gets in the way of sympathetic identification and that prevents this kind of narrative production. It is the immovability of the characters' theoretical positions, their delineation of political categories that actually prevents a common politics from developing. In Marxism and literature, Raymond Williams (1977: 129-130) writes that 'it is the reduction of the social to fixed forms that remains the basic error': social forms 'become social consciousness only when they are lived, actively, in real relationships'. In order to attend to the social content of an era, say, or a work of art or literature, it is crucial that we pay attention to specific feelings and rhythms rather than reducing them to 'belief systems, institutions, or explicit general relationships' (Williams 1977: 133). Equally, for Williams (1977: 146), generic, formal and disciplinary distinctions have historically inhibited the 'multiplicity of writing'. In Lessing's novel, the temporality of despair shapes a narrative logic of order and domination, of one thing coming inevitably after the other. In the same way that the group solidarity turns out to be no more than a means to an end - the group's act of militancy the only occasion for and logical outcome of this alternative community - so will Alice's naivety result in her sticky 
end. The closing lines of the novel describe Alice sitting at the kitchen table of the now empty house, waiting for her lunch with Peter Cecil, a British agent to whom she is likely to incriminate herself: 'like a nine-year-old girl who has had, perhaps, a bad dream, the poor baby sat waiting for it to be time to go out and meet the professionals' (Lessing 1985: 397). Within The good terrorist, all the plot points have a specific correlate, which is another way of saying that this is a narrative in which all actions have specific and already determined consequences. All the characters are called to answer for their actions. Such is the temporality of despair working at the level of form. When Alice gets Jim a job with her father's printing firm, Jim for whom 'nothing could ever seem ... more than a temporary good', it is almost inevitable that it will end in disaster (Lessing 1985: 81). Alice's subsequent burgling of her father's office has predictable results: Jim is blamed, and sacked. He disappears and, Alice reflects, no one in the squat has given 'a thought to him since' (Lessing 1985: 293). Alice is the only character seemingly unable, or perhaps unwilling, to arrive at the conclusions the narrative's telos of sequence calls for. To borrow a phrase from commons discourse, The good terrorist is a narrative of 'enclosure' in which tragedies occur as the logical outcome of trying to find alternatives to the exigencies of the world as it is.

One of the novel's most striking scenes shows Alice, with the help of Jim, clearing the attic at 43 Old Mill Road of buckets full of human excrement, a scene described at length and in excruciating detail. Alice carries the pails two by two to the pit she and Jim have dug in the garden, 'controlling her heaving stomach, in a miasma that did not seem to lessen, but rather spread from the house and the garden to the street' (Lessing 1985: 71). When Gayle Green (1992) argues that The good terrorist reflects the dimming of the great social dream of the 1960 s, she is of course referring to the historical realities of the gradual rolling back of welfare programmes, rising unemployment and industrial decline and deregulation. But she is also pointing up the loss of the capacity to envision a better world. The revolutionary 
activities the novel's characters undertake are limited to the madcap and reckless (as when Jasper and Bert travel to Russia) or to the senseless and brutal (the Knightsbridge bombing). The radical imagination of the novel's characters is constrained by circumstance, by the structural changes to everyday life in Britain and the attendant change in reigning political ideology. In Lessing's text, the optimism of the preceding decades thus reaches its terminus in a pit filled with faeces, a pit incidentally packed by the house's previous occupants with empty liquor bottles, and whose smell has already permeated the neighbourhood. Here again, present failure sits within past failure: the current generation of squatters find themselves, to no avail, going over the same ground as the group that preceded them.

\section{$\underline{\text { Literature in commons }}$}

The good terrorist is, as I have said, narrated in its entirety from the limited point of view of Alice; that is to say, a novel that depicts the possibilities and limitations of the commons and of revolutionary ideology from what ought to be a progressive point of view, is told without a narrative commons. The layer of irony this adds to the narrative is a forceful reassertion of the flaw in middle-class radicalism in its current form, and in the context of the 1980s: that even Alice, the most credible representative of commoning in the novel, still adheres to middle-class values and ideals of privacy, individuality, and property. Her logic, like that of the narrative, remains one of enclosure.

What, then, might a novel look like that performs its opposite? What kind of narrative might challenge the logic of enclosure? Key features of commoning practices include cooperation; establishing mechanisms to prevent accumulation of power; giving new meaning to existing practices and goods; creativity, play and passion; and ensuring the conditions for its reproduction. A closer examination of these elements and their potential applicability to literary texts will enable us to conceive of a literature of the commons and 
will contribute to discussions, ongoing and increasingly pressing in literary studies today, about the social uses of literature.

\section{References}

Bright, Gillian. 2015. Paper, ink, and the 'blood-stained inanity': The aesthetics of terrorist violence in Joseph Conrad's The secret agent, Paul Theroux's The family arsenal, and Doris Lessing's The good terrorist'. Critique: studies in contemporary fiction 56(2). 190-206.

Brown, Wendy. 2006. American nightmare: Neoliberalism, neoconservatism, and dedemocratization. Political Theory 34(6). 690-714.

Crewe, Tom. 2016. The strange death of municipal England. London Review of Books 38(24). 6-10.

Crook, A.D.H. 1988. Deregulation of private rented housing in Britain: Investors' responses to government housing policy in the 1980s. Built Environment 14(3/4). 155-167.

de Angelis, Massimo. 2016. Foreword. In Stavros Stavrides, Common space: the city as commons, xi-xiv. London: Zed Books.

Federici, Silvia. 2012. Revolution at point zero: Housework, reproduction, and feminist struggle. Oakland: PM Press.

Federici, Silvia \& George Caffentzis. 2014. Commons against and beyond capitalism. Community Development Journal 49(1). i92-i105.

Fisher, Mark. 2009. Capitalist realism: Is there no alternative? London: Zero Books.

Graeber, David. 2012. Dead zones of the imagination: on violence, bureaucracy, and interpretive labor. HAU: Journal of Ethnographic Theory 2(2). 105-128.

Graeber, David. 2015. The utopia of rules: On technology, stupidity, and the secret joys of bureaucracy. New York: Melville House.

Greene, Gayle. 1992. Bleak houses: Doris Lessing, Margaret Drabble and the condition of 
England. Forum for Modern Language Studies 28(4). 304-319.

Hall, Stuart. 1988. The hard road to renewal: Thatcherism and the crisis of the left. London: Verso.

Hay, Colin. 1992. Housing policy in transition: From the post-war settlement towards a 'Thatcherite' hegemony. Capital \& Class 16(1). 27-64.

Knight, Daniel \& Charles Stewart. 2016. Ethnographies of austerity: temporality, crisis and affect in southern Europe. History and Anthropology 27(1). 1-18.

Lalbaksh, Pedram \& Wan Roselezan Wan Yahya. 2012. Politics of feminine abuse: Political oppression and masculine obstinacy in Doris Lessing's The good terrorist. International Journal of Applied Linguistics and English Literature 1(3), http://www.doaj.org. (24 April 2018.)

Lessing, Doris. 1985. The good terrorist. London: Jonathan Cape.

Scanlan, Margaret. 1990. Language and the politics of despair in Doris Lessing's The good terrorist. Novel: A Forum on Fiction 23(2). 182-198.

Stavrides, Stavros. 2016. Common space: The city as commons. London: Zed Books.

Tronto, Joan C. 1993. Moral boundaries: A political argument for an ethic of care. London: Routledge.

Vasudevan, Alexander. 2017. The autonomous city: A history of urban squatting. London: Verso.

Williams, Raymond. 1983. Keywords: A vocabulary of culture and society, rev. edn. Oxford: OUP.

Williams, Raymond. 1977. Marxism and literature. Oxford: OUP. 